\title{
Treatment of compound tibia fracture with microvascular latissimus dorsi flap and the llizarov technique : A cross-sectional study of long-term outcomes
}

\author{
Repo, J.P.
}

2016-04

Repo , J P , Barner-Rasmussen , I , Roine , R P , Sintonen , H \& Tukiainen, E J 2016 , '

Treatment of compound tibia fracture with microvascular latissimus dorsi flap and the llizarov technique : A cross-sectional study of long-term outcomes ', Journal of Plastic, Reconstructive \& Aesthetic Surgery, vol. 69 , no. 4 , pp. 524-532 . https://doi.org/10.1016/j.bjps.2015.12.011

http://hdl.handle.net/10138/223908

https://doi.org/10.1016/j.bjps.2015.12.011

publishedVersion

Downloaded from Helda, University of Helsinki institutional repository.

This is an electronic reprint of the original article.

This reprint may differ from the original in pagination and typographic detail.

Please cite the original version. 


\title{
Treatment of compound tibia fracture with microvascular latissimus dorsi flap and the Ilizarov technique: A cross-sectional study of long-term outcomes ${ }^{\text {th }}$
}

\author{
J.P. Repo ${ }^{\text {a,* }}$, I. Barner-Rasmussen ${ }^{\text {a }}$, R.P. Roine ${ }^{\text {b,c }}$, \\ H. Sintonen ${ }^{d}$, E.J. Tukiainen ${ }^{a}$
}

\author{
a Department of Plastic Surgery, University of Helsinki and Helsinki University Hospital, HUS, Helsinki, \\ Finland \\ ${ }^{\mathrm{b}}$ Group Administration, University of Helsinki and Helsinki University Hospital, Helsinki, Finland \\ c Department of Health and Social Management, Research Centre for Comparative Effectiveness and \\ Patient Safety, University of Eastern Finland, Kuopio, Finland \\ ${ }^{\mathrm{d}}$ Department of Public Health, University of Helsinki, Helsinki, Finland
}

Received 2 October 2015; accepted 22 December 2015

\section{KEYWORDS}

Tibia fracture; Latissimus dorsi; Muscle flap; Lower extremity reconstruction; Ilizarov; Distraction osteogenesis

\begin{abstract}
Summary Background: Extensive compound tibial fractures present reconstructive challenges. The present study aimed to assess the outcomes of microvascular latissimus dorsi (LD) flap combined with the Ilizarov technique for extensive compound tibial fractures with bone loss and bone healing complications.

Methods: Patient records were reviewed retrospectively. The Lower Extremity Functional Scale (LEFS), the Disabilities of the Arm, Hand and Shoulder (DASH), and the 15D healthrelated quality of life (HRQoL) instrument were applied.

Results: Between 1989 and 2014, 16 patients underwent reconstruction with a microvascular LD flap and bone transport $(11 / 16)$ or late bone lengthening $(5 / 16)$. The mean clinical follow-up time was 6.6 (standard deviation (SD): 6.5) years. Three patients had minor complications requiring reoperation. Partial necrosis of one flap required late flap reconstruction in one case. Late bone grafting was used to enhance union in eight of 16 cases. The mean new bone gain was $3.8 \mathrm{~cm}$ (SD: 2.5$)$.

Overall, 11 patients completed the questionnaires in a mean of 22.3 years (SD: 2.4 ) after surgery. The main findings revealed a relatively good function of the reconstructed limb and good shoulder function. The mean HRQoL was comparable to that of an age-standardized sample of the general population.
\end{abstract}

\footnotetext{
This work has been presented as a poster in the 8th Congress of the Baltic Association of Surgeons 10/9/2015.

* Corresponding author. Department of Plastic Surgery, Helsinki University Hospital, P.O. Box 266, 00029 HUS, Finland.

E-mail address: mrjussirepo@gmail.com (J.P. Repo).
} 
Conclusion: Segmental tibia transport and lengthening to correct limb length discrepancy do not compromise the microvascular muscle flap. Combined microvascular LD flap reconstruction and the llizarov technique can be used in treating acute compound tibial defects, pseudoarthrosis, and osteitis, all associated with significant amputation risk. Fair long-term functional outcomes and HRQoL are achieved when these combined techniques are used.

(c) 2016 British Association of Plastic, Reconstructive and Aesthetic Surgeons. Published by Elsevier Ltd. All rights reserved.

\section{Introduction}

Compound tibia fracture with significant zone of injury or sequelae of bone healing complications can be managed with complex methods including the Ilizarov technique of distraction osteogenesis, ${ }^{1,2}$ the Masquelet technique, ${ }^{3}$ or vascular bone transfers, such as the iliac crest and fibula. ${ }^{4}$ In cases of extensive soft-tissue loss, local or pedicled muscle flaps or free flaps may be indicated. ${ }^{5}$ Tibia lengthening by distraction osteogenesis may also be used to correct posttraumatic limb length discrepancy. ${ }^{6,7}$

In 1989, Gavril Ilizarov introduced his technique of distraction osteogenesis. ${ }^{8,9}$ In this technique, the bone is stabilized with an external fixator and corticotomy is performed outside the fracture site, thereby enabling formation of new bone through distraction. Free muscle flap transfer combined with the Ilizarov technique to reconstruct lower-extremity compound defects has been previously described. ${ }^{1,10}$

There are several reports concerning assessment of the long-term outcomes of these combined techniques; however, only a few have focused on the long-term outcomes assessed by patient-reported outcome measures. In the present study, the microvascular LD flap and distraction osteogenesis was used in limb salvage of acute tibial defects with large zones of injury due to combined absolute bone defect and soft-tissue loss. This technique has also proven reliable in treating prolonged sequelae of complications including osteomyelitis and pseudoarthrosis with impaired bone blood circulation. An additional indication for external tibia distraction has been correction of late traumatic limb length discrepancy after microvascular flap reconstruction.

The present study aimed to assess the reliability of this combined method and to report the long-term outcomes of all patients with traumatic acute or chronic compound tibia defect treated with microvascular LD flap reconstruction and the llizarov distraction osteogenesis (either bone transport or lengthening) in the authors' institution between 1989 and 2014.

\section{Patients and methods}

The study was approved by the Ethics Committee of the Helsinki University Hospital. Patients were identified from the hospital records, and their patient records were retrospectively reviewed. Patients with femoral reconstruction, intramedullary distraction osteogenesis, fracture stabilization with external fixation only, and soft-tissue reconstruction other than LD were excluded. The results were reported following the STROBE ${ }^{11}$ guidelines for crosssectional studies.

\section{Outcome measures}

Shoulder function was examined by the main section of the Finnish version ${ }^{12}$ of the Disabilities of the Arm, Shoulder and Hand ${ }^{13}$ (DASH) questionnaire. It comprises 30 questions (physical activities, 23 questions; symptoms, seven questions). The DASH rewards a total score between 0 and 100 points. $^{13}$

The function of the reconstructed limb was assessed by the Finnish version ${ }^{14}$ of the Lower Extremity Functional Scale $^{15}$ (LEFS). It contains 20 function-related questions. The total score ranges between 0 and 80 , with higher scores representing better functional ability.

HRQoL was measured by the $15 D^{16}$ questionnaire. It is a comprehensive, 15-dimensional HRQoL instrument that compares positively with other analogous, generic HRQoL instruments. ${ }^{16-19}$ Incorporating population-based preference weights into the dimensions yields a single index score that ranges from 0 (equivalent to being dead) to 1 (best possible HRQoL). A difference $\geq 0.015$ in the $15 \mathrm{D}$ score is estimated to be clinically important. ${ }^{20}$ The authors hypothesized that the patients enjoy a HRQoL comparable to that of an age-standardized general population.

The level of physical activity was assessed by the frequency intensity time (FIT) index. ${ }^{21}$ The index is obtained by multiplying the scores of each question together, yielding a score between 0 and 100 (the higher the score, the greater the physical activity).

Finally, a questionnaire designed for the study charted comorbidities and the use of analgesics. A written informed consent was obtained from the patients participating in the cross-sectional assessment with patient-reported outcome measures.

\section{Statistical analysis}

Results are obtained as means with SD, medians, or ranges. HRQoL results of the patients were compared with those of an age-standardized sample of the general Finnish population ( $n=2413$ ) obtained from the Health 2011 Survey. ${ }^{22}$ The statistical significance of the differences between patients and the general population was compared using the independent samples $t$-test. A significance level was set at 
$p$-value $<0.05$. Analyses were performed with SPSS 20 (SPSS Inc., Chicago, IL, USA).

\section{Results}

Sixteen patients with traumatic compound tibial defect treated with a microvascular LD flap and the Ilizarov distraction osteogenesis (segmental bone transport, $n=11$; lengthening of the tibia, $n=5$ ) between the years 1989 and 2014 were identified. Their mean age was 33 years (SD 13.2). The trauma mechanism was automobile $(n=6)$, motorcycle $(n=3)$, moped $(n=1)$, or tractor $(n=1)$ collision, lift bar hit $(n=1)$, train accident $(n=1)$, fall $(n=2)$, or a blast (previous war injury) $(n=1)$. The trauma was of high energy in 14 of the 16 cases, leading to an open fracture in 13 . The patient characteristics together with the Gustilo-Anderson open fracture classification ${ }^{23}$ are presented in Table 1 . The defect location was metaphyseal $(n=8)$, meta-epiphyseal $(n=6)$, epiphyseal with intra-articular involvement $(n=1)$, or diaphyseal $(n=1)$.

The accompanying injuries included an ipsilateral femur fracture in three patients, metatarsal fracture in one, and a bilateral tibial pilon fracture in one patient. Five patients were smokers. One patient had type II diabetes. The remaining patients had no significant comorbidities.

The mean number of operations before microvascular transfer was 1.9 (SD: 1.3). In 15 of the 16 patients, revisions and external fixation were applied in the primary treatment facility. One patient had undergone previous reconstruction with a LD flap and three patients with local muscle flaps before admission. In one closed fracture patient, a leg cast had been used to stabilize the fracture. One patient presented with bone transport that began earlier $(9 \mathrm{~cm}$ of distracted bone) along with imminent extrusion of the bone. The size of the soft-tissue defect ranged from $4 \times 6$ to $10 \times 30 \mathrm{~cm}$. Loss of functional units was observed in 15 of the 16 patients (Table 1$)$.

\section{Soft-tissue reconstruction}

Patients underwent soft-tissue reconstruction with microvascular LD muscle $(n=10)$ or musculocutaneous $(n=6)$ flaps either early ( $<30$ days; $n=9$ ) (Figures. $1-6)$ or late ( $>30$ days) $(n=7)$. The median time from trauma to flap reconstruction was 18 days (range: 1 day-26.9 years), depending on when the patient was referred to the author's clinic. An additional microvascular iliac crest transfer (size: $4 \times 12 \mathrm{~cm}$ ) was performed in one patient with a very extensive injury, moving it to a more proximal area. Moreover, $8 / 16$ of patients underwent cancellous bone grafting to enhance bony union simultaneously with the flap reconstruction. The sizes of the microvascular flaps ranged between $3 \times 15$ and $15 \times 30 \mathrm{~cm}$.

The recipient arteries were the posterior $(n=10)$ or anterior tibial $(n=3)$, or popliteal vessels $(n=2)$. Either end-to-side $(n=9)$ or end-to-end $(n=7)$ anastomoses were used. Vein grafts from the great saphenous were used in two cases, and those from the cephalic vein were used in one case. The recipient veins were concomitant $(n=13)$, popliteal $(n=2)$, and posterior tibial $(n=1)$ vessels. Additional skin grafting was used in 15 of the 16 cases.

\section{Ilizarov technique}

Indications for bone reconstruction were large primary defect $(n=10)$, tibial length discrepancy $(n=6)$, longstanding pseudoarthrosis $(n=4)$, or nonunion $(n=2)$. Four patients had two or more of these indications. In the bone transport cases $(n=11)$, corticotomy was performed either simultaneously with $(n=4)$ or 1 day-2.8 years (median: 23 days) after microvascular flap reconstruction. The tibial bone was unifocally osteotomized above $(n=10)$ or beneath the defect $(n=1)$. A deep infection was present in two of the 11 patients when the transport process began.

Five of the 16 patients underwent tibia bone lengthening. The timing of corticotomy from the soft-tissue reconstruction in this group ranged between 67 days and 5.6 years (median: 2.1 years). One additional patient underwent lengthening for limb length discrepancy after completion of bone transport. In five of the six cases, the bone was osteotomized proximal to the defect.

The osteotomized bone ends were stabilized by external fixation with an Orthofix (Orthofix SRL, Verona, Italy; $n=10$ ), Fixel (AMP INC, Seattle, WA, USA; $n=3$ ), AO (DePuy Synthes, West Palm Beach, FL, USA; $n=2$ ), or an Ilizarov device (Smith \& Nephew Orthopedics, Memphis, TN, USA; $n=1$ ).

\section{Clinical follow-up}

The mean follow-up time was 6.6 years (SD: 6.5). Complications were encountered in 13 of the 16 patients (Table 2). Postoperatively, one patient had temporary peroneal palsy. Overall, 14 of the 16 patients underwent reoperations (Table 3). The mean time of external fixation was 178 days (SD: 99), thus resulting in 54 days/cm fixation index.

In the bone transport group, the mean time to full weight bearing and complete radiological bone union from the beginning of transport was 14.3 (SD: 12.7) and 16.0 (SD: 22.1) months, respectively. These data were unavailable for one patient. In this group, the median amount of new bone was $4 \mathrm{~cm}$ (range: $2.0-12.0 \mathrm{~cm}$ ). In the bone lengthening group (6/16), full weight bearing and radiological bone union was achieved in a median of 10.8 (SD: 16.6) and 32.2 (SD: 18.0) months, respectively. The median amount of new bone gained was $3.2 \mathrm{~cm}$ (range: $2.0-4.0 \mathrm{~cm}$ ).

Two patients experienced severe pain in the reconstructed limb requiring long-term analgesia with opioids. One patient had a permanent antecurvatum of $10^{\circ}$ and tibial varus of $5^{\circ}$. In the remaining patients, there were no rotational deformities and axial malalignment was $<5^{\circ}$. The overall mean tibial length discrepancy after treatment was $2.0 \mathrm{~cm}$ (SD: 1.1). In addition, ipsilateral femoral shortening of 2 and $3 \mathrm{~cm}$ was observed in two patients, respectively.

One patient in the lengthening group and seven of the 11 patients in the transport groups required special insoles. Furthermore, five of the 16 patients had clinically impaired ankle motion (dorsiflexion). One patient had limited knee joint mobility. However, all the patients were able to ambulate independently.

The working status was available for 13 of the 16 patients. Twelve of the 13 patients returned to work. 


\begin{tabular}{|c|c|c|c|c|c|c|c|c|c|c|}
\hline $\begin{array}{l}\text { No./age/ } \\
\text { sex }\end{array}$ & $\begin{array}{l}\text { Trauma } \\
\text { mechanism }\end{array}$ & $\begin{array}{l}\text { Gustilo } \\
\text { grade }\end{array}$ & $\begin{array}{l}\text { Soft tissue } \\
\text { defect }(\mathrm{cm})\end{array}$ & Loss of functional units & $\begin{array}{l}\text { Time } \\
\text { to flap } \\
\text { (d) }\end{array}$ & $\begin{array}{l}\text { Bone } \\
\text { defect } \\
(\mathrm{cm})\end{array}$ & $\begin{array}{l}\text { From flap } \\
\text { to bone } \\
\text { distraction }\end{array}$ & $\begin{array}{l}\text { Fixation } \\
\text { time }\end{array}$ & $\begin{array}{l}\text { Time for } \\
\text { union (d) }\end{array}$ & $\begin{array}{l}\text { New } \\
\text { bone } \\
(\mathrm{cm})\end{array}$ \\
\hline $1 / 50 / \mathrm{W}$ & Fall $(3 \mathrm{~m})$ & IIIC & $2 \times 5$ & $\begin{array}{l}\text { Partial injury of the tibial } \\
\text { nerve }\end{array}$ & 25 & 5 & 428 & 208 & 1334 & 2 \\
\hline $2 / 42 / M$ & $\mathrm{~A}$ & IIIC & $10 \times 20$ & $\begin{array}{l}\text { Partial loss of posterior } \\
\text { tibial m., } 10-\mathrm{cm} \text { tendon } \\
\text { loss }\end{array}$ & 13 & 7 & 0 & 369 & 1623 & 6 \\
\hline $3 / 31 / M$ & Grenade & IIIC & $10 \times 10$ & $\begin{array}{l}\text { Partial loss of tibialis } \\
\text { anterior }\end{array}$ & 361 & 12 & 0 & 116 & $\mathrm{~N} / \mathrm{A}$ & 12 \\
\hline $4 / 47 / M$ & A & IIIB & $5 \times 5$ & $\begin{array}{l}\text { Partial loss of } \\
\text { gastrognemius and of } \\
\text { anterior tibial } \mathrm{m} \text {. }\end{array}$ & 8526 & 4.5 & 0 & 151 & 197 & 3 \\
\hline $5 / 15 / M$ & Train & IIIB & $5 \times 10$ & $\begin{array}{l}\text { Partial loss of tibialis } \\
\text { anterior and of EDC }\end{array}$ & 5 & 7 & 1 & 153 & 836 & 7 \\
\hline $6 / 47 / M$ & A & IIIC & $7 \times 20$ & $\begin{array}{l}\text { Partial loss of soleus and } \\
\text { gastrocnemius }\end{array}$ & 1 & 7 & 45 & 105 & 676 & 7 \\
\hline $7 / 22 / M$ & $\begin{array}{l}\text { Motorcycle } \\
\text { accident }\end{array}$ & IIIC & $10 \times 15$ & $\begin{array}{l}\text { Partial loss of } \\
\text { gastrocnemius }\end{array}$ & 14 & 8 & 80 & 116 & 447 & 5.5 \\
\hline $8 / 44 / M$ & $\begin{array}{l}\text { Motorcycle } \\
\text { accident }\end{array}$ & - & $7 \times 1$ & Anterior tibial $\mathrm{m}$. & 9440 & 5 & 0 & 167 & 244 & 3.5 \\
\hline $9 / 23 / M$ & A (rally) & IIIC & $15 \times 20$ & $\begin{array}{l}\text { Anterior compartment, } \\
\text { partial loss of } \\
\text { gastrocnemius }\end{array}$ & 9 & 12 & 63 & 126 & 393 & 4 \\
\hline $10 / 24 / M$ & $A$ & IIIB & $15 \times 8$ & Anterior compartment & 10 & 5 & 0 & 160 & 720 & 3 \\
\hline $11 / 15 / M$ & $\begin{array}{l}\text { Moped } \\
\text { accident }\end{array}$ & IIIA & $10 \times 10$ & $\begin{array}{l}\text { Peroneus, flexor } \\
\text { digitorum longus }\end{array}$ & 19 & 3 & 1036 & 105 & 269 & 3 \\
\hline $12 / 44 / M$ & $A$ & IIIB & $5 \times 8$ & Anterior compartment & 15 & 3 & 2055 & $158(\mathrm{~L})$ & 347 & 3 \\
\hline $13 / 49 / M$ & Lift bar hit & - & $1 \times 1$ & Anterior compartment & 971 & 3 & 347 & 137 (L) & 1444 & 4 \\
\hline $14 / 33 / \mathrm{W}$ & Fall & - & $8 \times 8$ & Anterior compartment & 548 & 5 & 67 & 396 (L) & 1794 & 2 \\
\hline $15 / 21 / M$ & $A$ & IIIB & $6 \times 8$ & $\begin{array}{l}\text { Partial loss of } \\
\text { gastrognemius }\end{array}$ & 7 & $3-4$ & 1098 & $54(\mathrm{~L})$ & 880 & 1.5 \\
\hline $16 / 18 / M$ & $\begin{array}{l}\text { Motorcycle } \\
\text { accident }\end{array}$ & IIIC & $10 \times 20$ & Anterior compartment & 31 & 5 & 436 & 244 (L) & 676 & 4 \\
\hline
\end{tabular}

$\mathrm{d}$, days; L, bone lengthening; A, automobile accident; $y$, years; $M$, man; W, woman; EDC, extensor digitorum communis; N/A, not available.

However, four patients had to shift to lighter work. The youngest patient in the study finished school and chose an occupation requiring physical activity.

\section{Long-term measurement outcomes}

Two patients were excluded from the mailing list due to unknown addresses. The response rate was $11 / 14$. The mean time from soft-tissue reconstruction to questionnaire follow-up was 22.5 years (SD: 2.4 ).

The mean DASH score, measuring the donor-site function, was 8.9 (SD: 6.7). The most frequent limitations were associated with heavy household chores and recreational activities during which force or impact is applied through the arm.

Concerning the reconstructed site, the LEFS revealed a mean overall score of 59 points (SD: 8.6) in the bone transport group, whereas the lengthening group received a mean of 62 points (SD: 5.3). The mobility of patients was most limited when running on uneven ground or hopping.
The 15D instrument revealed that the mean HRQoL score of patients was 0.907 and that of the age-standardized sample of the general population 0.931 (Figure 7). The difference is clinically important but not statistically significant. The patients were statistically significantly worse off on the dimensions of "moving" ( $p<0.01)$, "usual activities" $(p<0.01)$, and "discomfort and symptoms" $(p<0.001$; Figure 7$)$.

The mean FIT index was 36 (SD: 22). All patients were physically active with seven of the 11 patients cycling, swimming, or performing gym exercises, and four of the 11 patients making walking rounds. Finally, the questionnaire designed for the study revealed that one patient required mild analgesics.

\section{Discussion}

Only a few articles have assessed the long-term outcomes of extensive compound tibial defects treated with combined free LD flap coverage and Ilizarov distraction 


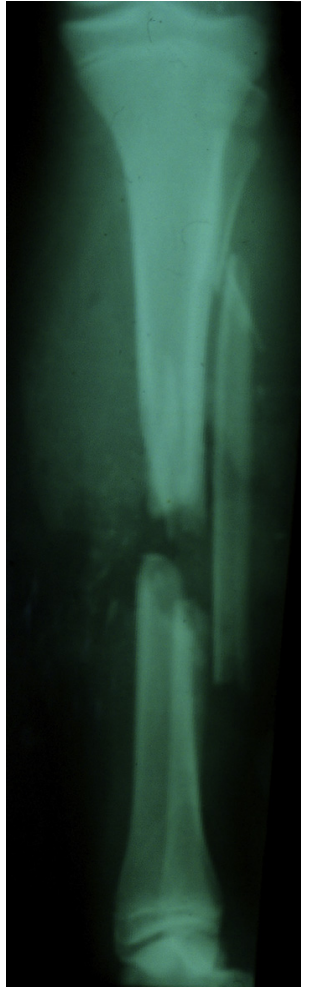

Figure 1 Patient no. 5. AP radiograph demonstrating an extensive primary tibial bone defect on the day of injury.

osteogenesis. The present study assessed the long-term outcomes of this combined method with a retrospective review of patient records and a cross-sectional evaluation with patient-reported outcome measures. The outcomes of this study confirmed that the combined method of free LD flap reconstruction and llizarov bone transport or bone lengthening does not compromise the free muscle flap. Furthermore, fair long-term functional outcomes of both donor site and reconstructed limb and the relatively good long-term HRQoL outcome support the use of this combined technique in selected patients.

In reconstruction of compound tibial defects, local or pedicled flap options such as the soleus or gastrocnemius are used. ${ }^{5}$ However, in extensive soft-tissue loss, local flaps are frequently unavailable because of damage or loss of local muscle units. In selected cases, microvascular transfers including the fasciocutaneous ALT, ${ }^{24}$ or serratus, ${ }^{6}$ and LD flaps ${ }^{25}$ are indicated. In the authors' institution, the LD flap was largely used because of its relatively large and long vessels and significant amount of muscle bulk.

It has been claimed that after raising the LD flap, the function of the shoulder increases with time. ${ }^{26}$ In a study conducted by Koh and Morris ${ }^{27}$ on a series of 18 patients, a mean of 18/100 DASH points after a follow-up time of 1.5 years was reported and overall $6 / 18$ scored $\geq 30$ points. Furthermore, Giardano et al. ${ }^{28}$ showed that limitations of the shoulder motion and weakness might appear with time. A recent systematic review concluded that shoulder movement is restored to close to its natural range in the long term. ${ }^{29}$ The present study revealed a mean DASH score of 8.9 points (very good function). Moreover, none scored $>19$ points. The long-term functional results of the microvascular LD donor site are encouraging in the present patients.

Conventionally, cancellous bone grafting has been described for bone defects $<5 \mathrm{~cm} .{ }^{30}$ However, in larger defects and in cases of prolonged sequelae of deep infection or pseudoarthrosis, more demanding methods of bone transfers, such as microvascular fibula and iliac crest flaps, are indicated. ${ }^{4}$ The fibula is the workhorse of lower limb long bone microvascular reconstruction. When it is raised as an osteocutaneous flap, it can be used to reconstruct infected compound tibial defects of size $10 \times 20 \mathrm{~cm} .{ }^{25}$ The microvascular iliac crest transfer provides a significant amount of bone bulk. However, the use of fibula has disadvantages. Even when raised with a skin island, the quantity of soft-tissue is relatively small and the risk of refracture is high. ${ }^{4,25}$ In these cases, additional microvascular muscle transfers such as LD are needed.

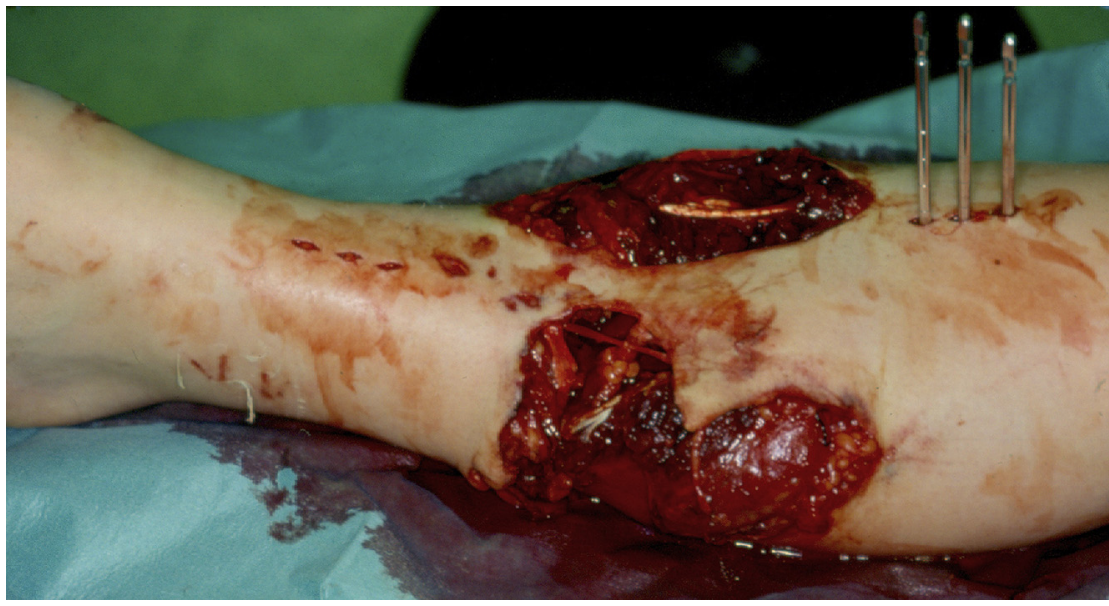

Figure 2 Intraoperative photograph illustrating Gustilo grade IIIC open fracture of the tibia with a large zone of injury and softtissue loss. 


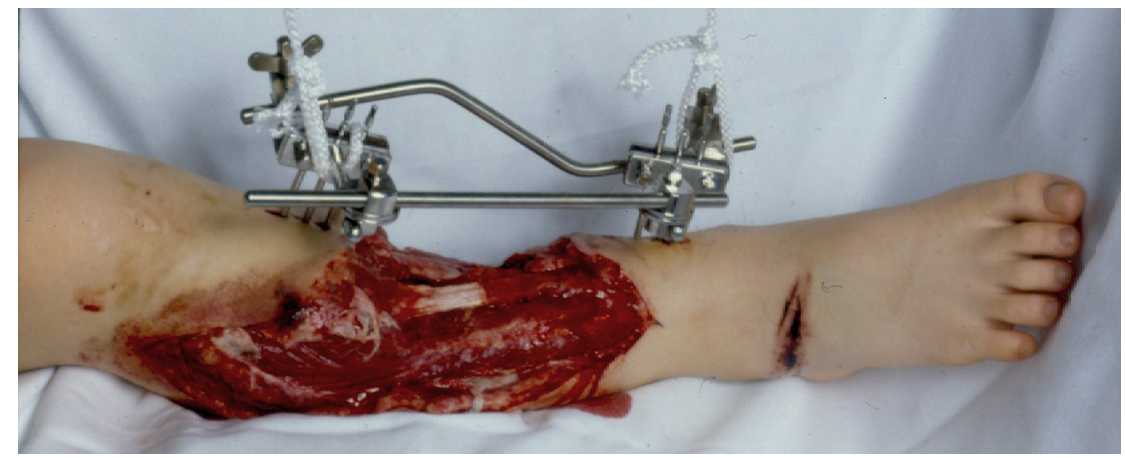

Figure 3 Intraoperative photograph demonstrating the soft-tissue defect after debridement.

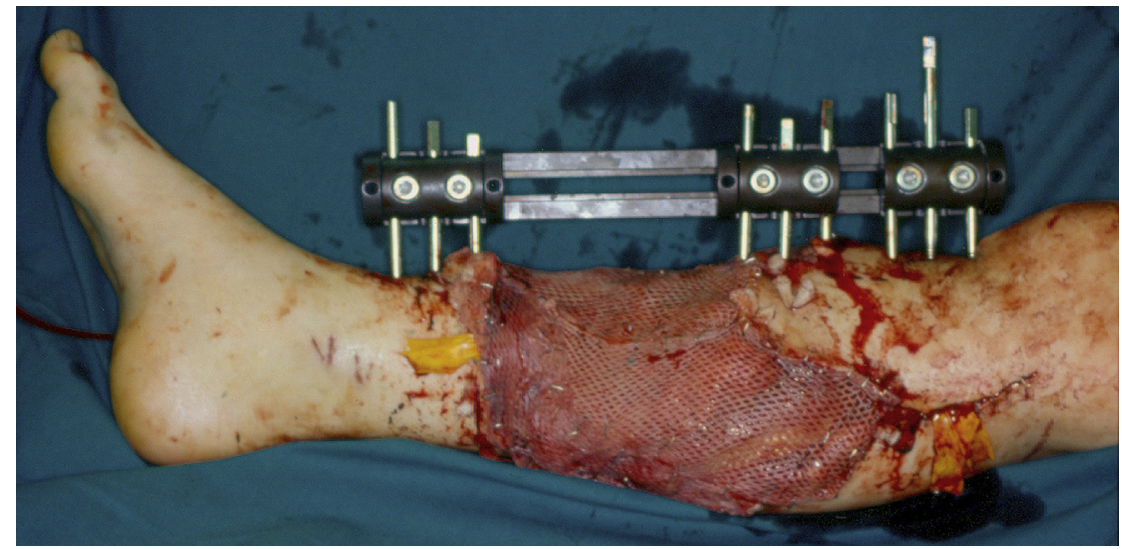

Figure 4 Postoperative photograph after proximal corticotomy, external fixation, and reconstruction with a microvascular latissimus dorsi flap. The muscle part of the flap is covered with split-skin grafting.

The Masquelet technique of applying a temporary antibiotic cement spacer has proven reliable in the reconstruction of large tibia defects. ${ }^{31}$ However, the cement spacer needs to be replaced with a cancellous bone graft in a later operation. Later bone grafting was used in five of the 11 cases of bone transport in the present series.

Recent reports concerning the long-term results of muscle flap reconstruction and tibia distraction for extensive primary defects with absolute bone loss or prolonged sequelae of infection and pseudoarthrosis are encouraging. ${ }^{2,3,32,33}$ However, it remains indisputable that the main disadvantage of the llizarov technique is the tedious process with external fixation that may take months to perform. Intense pin-track pain appeared in two patients. Furthermore, the distraction stretches the surrounding soft-tissues and nerves of the tibial region, which may lead to chronic pain. In such cases of intense pain and discomfort, prolonged treatment or even sometimes amputation may be indicated.

Previous studies suggest that the there is no risk of failure of free flap anastomoses due to distraction. ${ }^{11,34}$ The present study supports these findings with no anastomotic flap complication during or after the distraction process. The distraction area was chosen in such a way that it avoided direct stretching of the pedicle. Moreover, pin-site infections using the Ilizarov technique occur in 5\% of the cases. ${ }^{35}$ In the present series, six out of 16 patients had pin- site infection during the distraction. According to its severity, the pin-site infection was treated with local antiseptics, systemic antibiotics, or pin-site revisions. Furthermore, after completion of the bone transport, complications including malunion or secondary limb length discrepancy may require late corrections with opening wedge osteotomy or bone lengthening.

Tibia limb length discrepancy may have a negative impact on function and HRQoL. ${ }^{7}$ In the selected cases, lengthening using the Ilizarov distraction method after softtissue reconstruction was indicated. In the present series, six patients underwent correction of limb length discrepancy (in one patient following bone transport). The longterm outcomes in the present study support the use of this technique. It is worth correcting even moderate limb length discrepancy in selected cases.

A systematic review and meta-analysis of Ilizarov tibia distraction osteogenesis revealed a 60-100\% union and $2.9 \%$ secondary amputation rate. ${ }^{35}$ In the present series, bony union was achieved in all cases and no secondary amputations were needed. Schep et al. ${ }^{7}$ reported a mean LEFS score of 47 and 62 points in three patients who underwent bone transport and four patients with tibia lengthening, respectively. These results are not directly comparable as no soft-tissue reconstruction was performed in their series. However, the functional outcomes compared favorably in the bone transport group, and in the 


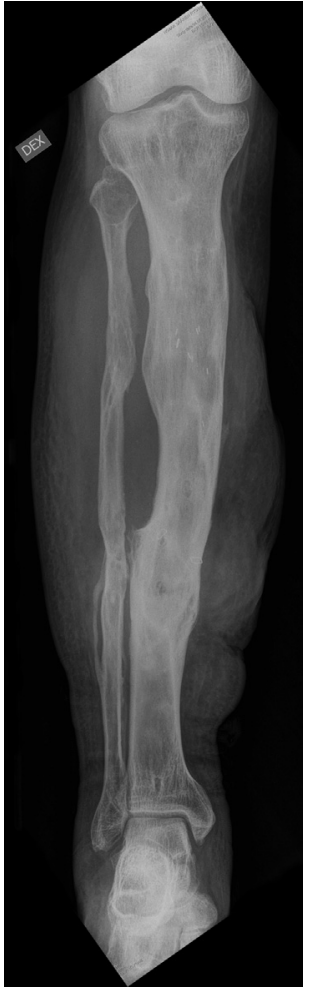

Figure 5 AP radiograph 16 years after bone reconstruction demonstrating $7 \mathrm{~cm}$ of new bone and achieved bone union of the reconstructed site.

lengthening group they correlated with those of Schep et al. In addition, adequate soft-tissue reconstruction preceding bone elongation/transport may contribute favorably to the outcome and even promote limb salvage.

In the HRQoL assessment by Knappinger et al. ${ }^{33}$ of a group quite similar to the present study, a high physical and low mental score of SF-36 modules compared to the general population was found at a mean of 3.6 years after trauma. In the present series, the follow-up assessment revealed decreased mobility and higher discomfort and symptoms compared to those of an age-standardized general population. Furthermore, the mental function score was comparable to that in the general population.

To the authors' knowledge, the present series is the largest describing the combined use of microvascular LD flap reconstruction and Ilizarov distraction osteogenesis.
Table 2 Complications in 13 of the 16 patients.

\begin{tabular}{ll}
\hline Complication & $n$ \\
\hline Flap & 2 \\
Thrombosis & 1 \\
Infection & 2 \\
Fistulation & 1 \\
Partial flap necrosis & \\
Bone transport & 3 \\
Pin-site infection & 1 \\
Fistulation & 3 \\
Delayed union & 2 \\
Osteomyelitis & 2 \\
Pseudoarthrosis & 4 \\
Refracture & 3 \\
Malunion & \\
Bone lengthening & 3 \\
Pin-site infection & 2 \\
Fistulation & 2 \\
Osteomyelitis & \\
\hline
\end{tabular}

Table 3 Reoperations in 14 of the 16 patients.

\begin{tabular}{ll}
\hline Reoperation & $n$ \\
\hline Flap & 4 \\
Revision & 2 \\
Reanastomosis & 1 \\
Vein grafting & 1 \\
Flap debulking & \\
Transport & 1 \\
Revision & 2 \\
EF refixation & 5 \\
Bone grafting & 1 \\
Bioglasses & 2 \\
Malunion correction & 1 \\
IMN placement & 1 \\
Lenghtening & 3 \\
Revision & \\
Bone grafting & \\
\hline
\end{tabular}

$E F$, external fixation; IMN, intramedullary nail.

Further strengths of the present study are a comprehensive assessment with validated patient-reported outcome measures, ${ }^{13,14,16}$ and comparison of HRQoL with that of the general population. Nevertheless, the small study group

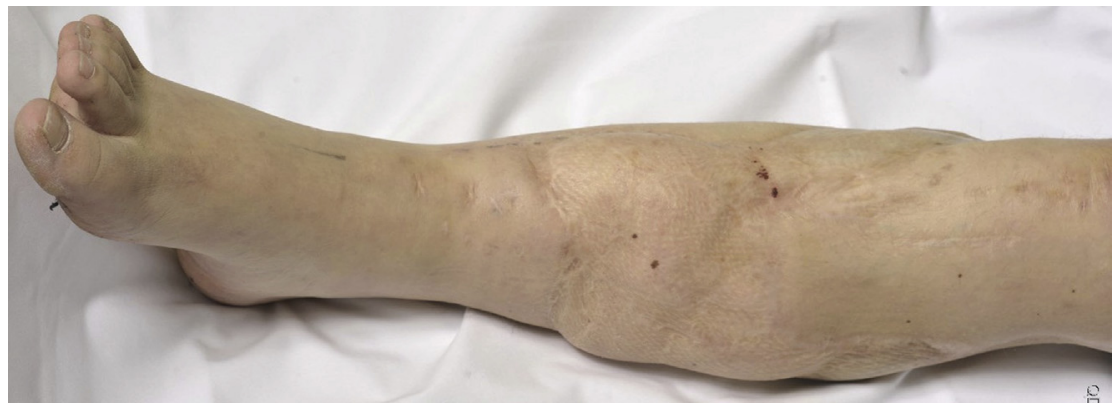

Figure 6 The clinical aspect 16.5 years after soft-tissue reconstruction. 


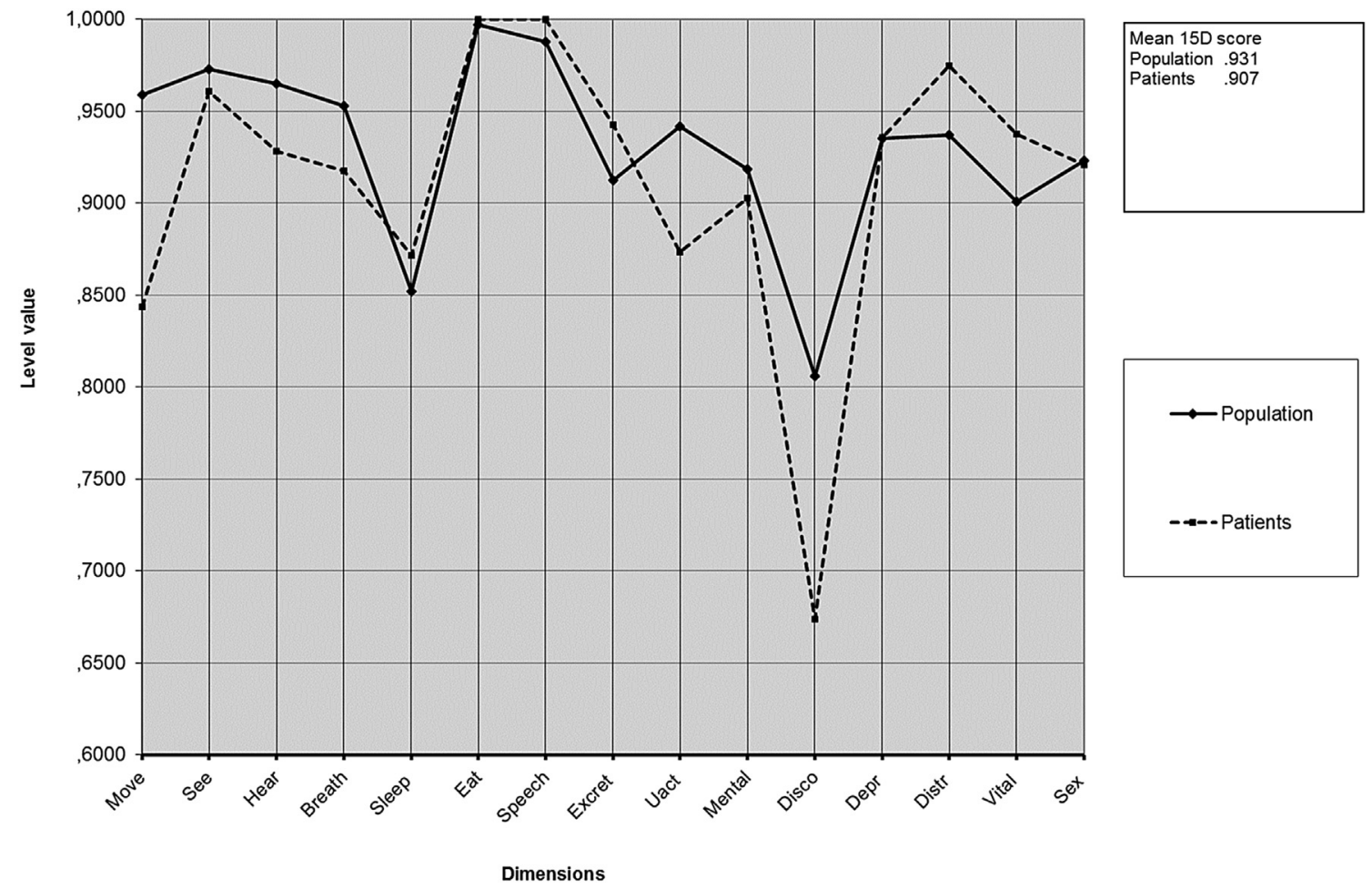

Figure 7 The mean 15D profile of the 11 patients, treated with a method combining the microvascular latissimus dorsi flap and the llizarov technique, and that of an age-standardized sample of the general population.

limits the generalizability of the results, and no data from alternative methods were available for comparison of the results.

In conclusion, the combined technique of microvascular LD flap and Ilizarov distraction osteogenesis is reliable for treating traumatic tibial compound defects with extensive soft-tissue and bone loss at a high risk of amputation. It is also useful for prolonged sequelae of infection and pseudoarthrosis and in correcting limb length discrepancy. However, patients should be meticulously selected because of the long distraction process and inconvenience of the external fixation. The procedure's long-term functional ability and HRQoL are relatively good.

\section{Conflicts of interest statement}

JPR: none.

IBR: none.

RPR: none.

HS: none.

EJT: none.

\section{Acknowledgment}

The authors would like to thank Jaana Jäppinen and Heli Sarpila for their contribution to data collection.

\section{References}

1. Tukiainen E, Asko-Seljavaara S. Use of the Ilizarov technique after a free microvascular muscle flap transplantation in massive trauma of the lower leg. Clin Orthop Relat Res 1993; 297:129-34.

2. Lowenberg DW, Buntic RF, Buncke GM, Parrett BM. Long-term results and costs of muscle flap coverage with Ilizarov bone transport in lower limb salvage. J Orthop Trauma 2013;27: $576-81$.

3. Rigal S, Merloz P, Le Nen D, Mathevon H, Masquelet AC. Bone transport techniques in posttraumatic bone defects. Orthop Traumatol Surg Res 2012;98:103-8.

4. Yazar S, Lin C-H, Wei FC. One-stage reconstruction of composite bone and soft-tissue defects in traumatic lower extremities. Plast Reconstr Surg 2004;114:1457-66.

5. Wagels M, Rowe D, Senewiratne S, Read T, Theile DR. Soft tissue reconstruction after compound tibial fracture: 235 cases over 12 years. J Plast Reconstr Aesthet Surg 2015;68:1276-85.

6. Sen C, Kocaoglu M, Eralp L, Gulsen M, Cinar M. Bifocal compression-distraction in the acute treatment of grade III open tibia fractures with bone and soft-tissue loss: a report of 24 cases. J Orthop Trauma 2004;18:150-7.

7. Schep NW, van Lieshout EM, Patka P, Vogels LM. Long-term functional and quality of live assessment following posttraumatic distraction osteogenesis of the lower limb. Strateg Trauma Limb Reconstr 2009;4:107-12.

8. Ilizarov GA. The tension-stress effect on the genesis and growth of tissues. Part I. The influence of stability of fixation and soft-tissue preservation. Clin Orthop Relat Res 1989;238: 249-81.

9. Ilizarov GA. The tension-stress effect on the genesis and growth of tissues: part II. The influence of the rate and frequency of distraction. Clin Orthop Relat Res 1989;239:263-85. 
10. Jupiter JB, Kour AK, Palumbo MD, Yaremchuck MJ. Limb reconstruction by free-tissue transfer combined with the Ilizarov method. Plast Reconstr Surg 1991;88:943-51.

11. Vandenbroucke JP, von Elm E, Altman DG, et al. Strengthening the reporting of observational studies in epidemiology (STROBE): explanation and elaboration. Int J Surg 2014;12: 1500-24.

12. Aro H, Hacklin E, Madanat R, Stranberg N. DASH-kyselykaavakkeen suomentaminen ja kulttuuriadaptaatio. Suom Ortop ja Traumatol 2009;32:252-4.

13. Hudak PL, Amadio PC, Bombardier C, The Upper Extremity Collaborative Group (UECG). Development of an upper extremity outcome measure: the DASH (disabilities of the arm, shoulder and hand). Am J Ind Med 1996;29:602-8.

14. Repo JP, Tukiainen EJ, Roine RP, Ilves $O$, Järvenpää S, Häkkinen A. Lower extremity functional scale (LEFS) -kyselylomakkeen suomen kielisen version luotettavuus ja validiteetti. Suom Ortop ja Traumatol 2015;38:205.

15. Binkley JM, Stratford PW, Lott SA, Riddle DL. The lower extremity functional scale (LEFS): scale development, measurement properties, and clinical application. North American orthopaedic rehabilitation research network. Phys Ther 1999; 79:371-83.

16. Sintonen $\mathrm{H}$. The $15 \mathrm{D}$ instrument of health-related quality of life: properties and applications. Ann Med 2001;33:328-36.

17. Stavem K. Reliability, validity and responsiveness of two multiattribute utility measures in patients with chronic obstructive pulmonary disease. Qual Life Res 1999;8:45-54.

18. Hawthorne G, Richardson J, Day NA. A comparison of the assessment of quality of life (AQDL) with four other generic utility instruments. Ann Med 2001;33:358-70.

19. Moock J, Kohlmann T. Comparing preference-based quality-oflife measures: results from rehabilitation patients with musculoskeletal, cardiovascular, or psychosomatic disorders. Qual Life Res 2008;17:485-95.

20. Alanne S, Roine RP, Räsänen P, Vainiola T, Sintonen H. Estimating the minimum important change in the $15 \mathrm{D}$ scores. Qual Life Res 2015;24:599-606.

21. Kasari DS. The effects of exercise on serum lipid levels in college women. Unpublished Master's Thesis. Missoula: University of Montana; 1976. p. 46.

22. Report 68/2012. Helsinki. In: Koskinen S, Lundqvist A, Ristiluoma N, editors. Health, functional capacity and welfare in Finland in 2011. National Institute for Health and Welfare (THL); 2012.
23. Gustilo RB, Mendoza RM, Williams DN. Problems in the management of type III (severe) open fractures: a new classification of type III open fractures. J Trauma 1984;24:742-6.

24. Yang YF, Xu ZH, Zhang GM, et al. Modified classification and single-stage microsurgical repair of posttraumatic infected massive bone defects in lower extremities. J Reconstr Microsurg 2013;29:593-600.

25. Knobloch K, Herold C, Vogt PM. Free latissimus dorsi flap transfer for reconstruction of soft tissue defects of the lower extremity. Oper Orthop Traumatol 2012;24:122-30.

26. Spears SL, Hess CL. A review of the biomechanical and functional changes in the shoulder following transfer of the latissimus dorsi muscles. Plast Reconstr Surg 2005;115:2070-3.

27. Koh CE, Morrison WA. Functional impairment after latissimus dorsi flap. ANZ J Surg 2009;117:1387-94.

28. Giordano S, Kääriäinen K, Alavaikko J, Kaistila T, Kuokkanen H. Latissimus dorsi free flap harvesting may affect the shoulder joint in long run. Scand J Surg 2011;100:202-7.

29. Lee KT, Mun GH. A systematic review of functional donor-site morbidity after latissimus dorsi muscle transfer. Plast Reconstr Surg 2014;134:303-14.

30. Myeroff $C$, Archdeacon M. Autogenous bone graft: donor sites and techniques. J Bone Jt Surg Am 2011;93:2227-36.

31. Karger C, Kishi T, Schneider L, Fitoussi F, Masquelet AC. Treatment of posttraumatic bone defects by the induced membrane technique. Orthop Traumatol Surg Res 2012;98: 97-102.

32. Chim H, Sontich JK, Kaufman BR. Free tissue transfer with distraction osteogenesis is effective for limb salvage of the infected traumatized lower extremity. Plast Reconstr Surg 2011;127:2364-72.

33. Krappinger D, Irenberger A, Zegg M, Huber B. Treatment of large posttraumatic tibial bone defects using the Ilizarov method: a subjective outcome assessment. Arch Orthop Trauma Surg 2013;133:789-95.

34. Hollenbeck ST, Woo S, Ong S, Fitch RD, Erdmann D, Levin LS. The combined use of the Ilizarov method and microsurgical techniques for limb salvage. Ann Plast Surg 2009 May;62(5): 486-91.

35. Papakostidis C, Bhandari M, Giannoudis PV. Distraction osteogenesis in the treatment of long bone defects of the lower limbs: effectiveness, complications and clinical results; a systematic review and meta-analysis. Bone Jt J 2013;95: 1673-80. 